Portland State University

PDXScholar

\title{
Newcomer Adjustment During Organizational Socialization: A Meta-Analytic Review of Antecedents, Outcomes, and Methods
}

Talya N. Bauer

Portland State University, talyabauer@pdx.edu

Berrin Erdogan

Portland State University, berrine@sba.pdx.edu

Todd Bodner

Portland State University, tbodner@pdx.edu

Donald M. Truxillo

Portland State University

Jennifer S. Tucker

U.S. Army Research Institute

Follow this and additional works at: https://pdxscholar.library.pdx.edu/busadmin_fac

Part of the Human Resources Management Commons, and the Industrial and Organizational

Psychology Commons

Let us know how access to this document benefits you.

\section{Citation Details}

Bauer, T. N., Bodner, T., Erdogan, B., Truxillo, D. M., \& Tucker, J. S. (2007). Newcomer adjustment during organizational socialization: A meta-analytic review of antecedents, outcomes, and methods. Journal of Applied Psychology, 92(3), 707-721. doi:http://dx.doi.org/10.1037/0021-9010.92.3.707

This Article is brought to you for free and open access. It has been accepted for inclusion in Business Faculty Publications and Presentations by an authorized administrator of PDXScholar. Please contact us if we can make this document more accessible: pdxscholar@pdx.edu. 


\title{
Newcomer Adjustment During Organizational Socialization: A Meta- Analytic Review of Antecedents, Outcomes, and Methods
}

\author{
Talya N. Bauer, Todd Bodner, \\ Berrin Erdogan, and Donald M. Truxillo \\ Portland State University
}

\author{
Jennifer S. Tucker \\ U.S. Army Research Institute
}

\begin{abstract}
The authors tested a model of antecedents and outcomes of newcomer adjustment using 70 unique samples of newcomers with meta-analytic and path modeling techniques. Specifically, they proposed and tested a model in which adjustment (role clarity, self-efficacy, and social acceptance) mediated the effects of organizational socialization tactics and information seeking on socialization outcomes (job satisfaction, organizational commitment, job performance, intentions to remain, and turnover). The results generally supported this model. In addition, the authors examined the moderating effects of methodology on these relationships by coding for 3 methodological issues: data collection type (longitudinal vs. cross-sectional), sample characteristics (school-to-work vs. work-to-work transitions), and measurement of the antecedents (facet vs. composite measurement). Discussion focuses on the implications of the findings and suggestions for future research.
\end{abstract}

Keywords: socialization, newcomer adjustment, meta-analysis, organizational socialization tactics

Organizational socialization refers to the process by which newcomers make the transition from being organizational outsiders to being insiders. An interactionist perspective of both newcomer and organizational influence on the adjustment process (Reichers, 1987) characterizes the socialization literature. Rather than waning in importance over the years, socialization has become more important because individuals are more mobile. In fact, approximately $25 \%$ of U.S. workers are currently undergoing organizational socialization (Rollag, Parise, \& Cross, 2005), and individuals change jobs an average of 10.2 times over 20 years (Bureau of Labor Statistics, 2005). These changes suggest that new employee socialization or "onboarding" is a key issue for organizations and newcomers alike as individuals undergo socialization more often in their careers and organizations deal with newcomers more often because of elastic personnel needs. Thus, examining this process has important theoretical and practical implications (Bauer \& Elder, 2006).

Despite the strides made in socialization research, the literature remains fragmented. For example, it suffers from a lack of clarity in terms of the role adjustment plays in newcomer socialization, a lack of consistency in how constructs are measured (noted by E. W. Morrison, 2002), and a lack of understanding of the impact

Talya N. Bauer and Berrin Erdogan, School of Business Administration, Portland State University; Todd Bodner and Donald M. Truxillo, Department of Psychology, Portland State University; Jennifer S. Tucker, Infantry Forces Research Institute, U.S. Army Research Institute, Fort Benning, Georgia.

We thank David Cadiz and Greg Tensa for their help on this study. A draft of this article was presented at the annual meeting of the Academy of Management, Honolulu, Hawaii, August 2005.

Correspondence concerning this article should be addressed to Talya N. Bauer, School of Business, Portland State University, Portland, OR 97207. E-mail: TalyaB@sba.pdx.edu of sampling and data collection timing (noted by Bauer, Morrison, \& Callister, 1998). Summarizing the work to date and identifying areas for future research are important to unifying and advancing the socialization literature.

Thus, the first goal of this research was to integrate socialization research into a model of antecedents and outcomes of adjustment and to test this model using meta-analysis and path modeling Although narrative reviews of the literature exist (e.g., Ashforth, Sluss, \& Harrison, in press; Bauer \& Taylor, 2001; Bauer et al., 1998; Fisher, 1986; Saks \& Ashforth, 1997a; Wanous \& Colella, 1989), an empirical review of the socialization literature has yet to be conducted. The current study fills this void by proposing and testing a model of newcomer adjustment while building on previous literature to extend it. Our second goal was to study the effects of different methodological approaches by comparing them metaanalytically. Finally, our study makes a contribution by summarizing existing relationships and uncovering relationships that deserve further attention.

In the following pages, we introduce a model of newcomer adjustment. We first describe three socialization indicators and explain our choice of these variables as indicators of newcomer adjustment for the current meta-analysis. Next, we discuss antecedents and outcomes of newcomer adjustment. Finally, we introduce three potential moderators of newcomer adjustment.

\section{Model of Newcomer Adjustment During Socialization}

Figure 1 presents the model examined in this study. This model treats role clarity, self-efficacy, and social acceptance as three key indicators of newcomer adjustment. Information seeking and organizational socialization tactics are the proposed antecedents of newcomer adjustment, and job satisfaction, organizational commitment, job performance, intentions to remain, and turnover are the outcomes of newcomer adjustment. We proposed and tested this particular model for three reasons. First, from a theoretical 


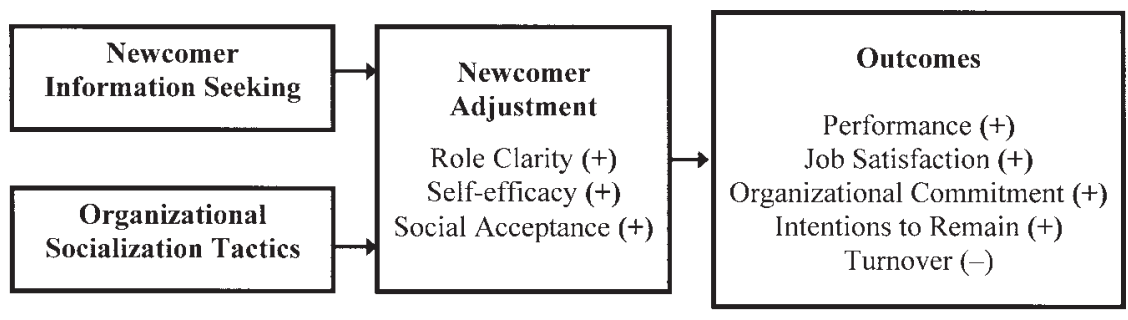

Figure 1. Antecedents and outcomes of newcomer adjustment during organizational socialization. Newcomer information seeking can be broken down into (a) referent information, (b) appraisal information, and (c) relational information, following Miller and Jablin (1991). For socialization tactics, high scores indicate institutionalized socialization. Organizational socialization tactics can be broken down into (a) content tactics, (b) context tactics, and (c) social tactics, following Jones (1986).

standpoint, the socialization process is one of uncertainty reduction (e.g., Berger, 1979). Uncertainty reduction theory posits that newcomers desire to increase the predictability of interactions between themselves and others within the new organization (Berger \& Calabrese, 1975). Second, the individual level of adjustment was an explicit main focus of our study, including the effects of both information seeking and organizational socialization tactics on outcomes. Finally, from a practical standpoint, this model represents the most commonly studied constructs in newcomer socialization (Bauer et al., 1998). Unlike a theoretical review article, which can include any potential constructs, a meta-analytic review is limited to relationships that have been consistently studied.

\section{What Is Newcomer Adjustment?}

Socialization researchers have tended to study similar adjustment indicators in a variety of ways. According to Fisher's (1986) review of the literature, newcomer adjustment following organizational entry consists of working through both task and social transitions. Similarly, Feldman (1981) noted that adjustment consists of three aspects (see Table 1). Resolution of role demands refers to understanding job tasks to perform and understanding task priorities and time allocation (role clarity). Task mastery refers to learning the tasks of the new job and gaining confidence in the role (self-efficacy). Adjustment to one's group refers to coming to feel liked and accepted by peers (social acceptance). Subsequently, researchers have frequently used role clarity, self- efficacy, and social acceptance as indicators of newcomer adjustment (e.g., Bauer et al., 1998). However, researchers have taken different approaches to the measurement of adjustment. It should be noted that learning is only a latent aspect of the adjustment facets focused on in this study. Whereas some investigators have taken the approach noted above to tap the latent construct of learning (e.g., Bauer \& Green, 1998; Feldman, 1976), others have measured adjustment more closely as actual learning and knowledge acquisition. For example, Ostroff and Kozlowski (1992) measured adjustment as a single global measure, and, more recently, researchers have developed more specialized measures of adjustment that tap learning regarding specific aspects of the job and organization directly (e.g., Chao, O'Leary-Kelly, Wolf, Klein, \& Gardner, 1994; Haueter, Macan, \& Winter, 2003; Ostroff \& Kozlowski, 1992; Taormina, 1994, 2004). Although these measures show great promise, to date, none has been used consistently across the socialization literature. For example, the Chao et al. (1994) scale has been studied the most frequently, but it has rarely been used in its entire form (for an exception, see Wesson \& Gogus, 2005), with researchers using only some of the dimensions.

\section{Antecedents of Newcomer Adjustment}

A decade after Fisher's (1986) review, Saks and Ashforth (1997a) presented a summary model of socialization that proposed information seeking and socialization tactics as antecedents of adjustment. We focused on these same influences on adjustment.

Table 1

Antecedents of Newcomer Adjustment: Information Seeking and Organizational Socialization Tactics

\begin{tabular}{lll}
\hline $\begin{array}{c}\text { Information seeking } \\
\text { (adapted from Miller \& Jablin, 1991) }\end{array}$ & $\begin{array}{c}\text { Organizational socialization tactics } \\
\text { (adapted from Jones, 1986) }\end{array}$ & $\begin{array}{c}\text { Newcomer adjustment } \\
\text { (adapted from Feldman, 1981) }\end{array}$ \\
\hline $\begin{array}{l}\text { Referent information: What is required to } \\
\text { function on the job? }\end{array}$ & $\begin{array}{c}\text { Content tactics: Clear stages exist for training, } \\
\text { and there is a clear timetable for role } \\
\text { adjustment. }\end{array}$ & $\begin{array}{c}\text { Role clarity/resolution of role demands: } \\
\text { Understanding the tasks to perform } \\
\text { for the job and understanding task } \\
\text { priorities and time allocation. }\end{array}$ \\
$\begin{array}{l}\text { Appraisal information: }: \text { Degree of functioning } \\
\text { successfully on the job. }\end{array}$ & $\begin{array}{c}\text { Context tactics: Learning task requirements as } \\
\text { part of a group and having formal training } \\
\text { before starting the actual job. }\end{array}$ & $\begin{array}{c}\text { tasks of the new job and gaining } \\
\text { confidence in the role. }\end{array}$ \\
$\begin{array}{l}\text { Relational information: Nature of } \\
\text { relationships with others. }\end{array}$ & $\begin{array}{c}\text { Social acceptance/adjustment to group: } \\
\text { Coming to feel liked and trusted by } \\
\text { and identity affirmation from organizational } \\
\text { insiders and having a trusted insider to } \\
\text { guide them within the organization. }\end{array}$ & peers. \\
\hline
\end{tabular}


Organizations (either passively or actively) create strong or weak situations under which newcomers must adjust to their new environments, representing different socialization tactics. Simultaneously (and perhaps in reaction to tactics), newcomers proactively seek information to help them adjust. A theoretical basis for both newcomer information seeking and organizational socialization tactics is the reduction of uncertainty newcomers experience on organizational entry. Organizations differ in terms of the goals they have for newcomers, ranging from conformity to innovation, and newcomers must learn what is expected of them through the adjustment process.

Information seeking. Van Maanen and Schein's (1979) first assumption for their theory of socialization was that newcomers will try to reduce uncertainty. Uncertainty reduction theory (Berger, 1979) argues that individuals do this to create predictable environments (Falcione \& Wilson, 1988). As Saks and Ashforth (1997a) noted, "Uncertainty is reduced through information provided via various communication channels, notably social interactions with superiors and peers" (p. 236). Louis (1980) also noted that a key input to the sense-making process is information from organizational insiders. Because reality testing is an important aspect of sense making, having insiders serve as "sounding boards" and provide background information is critical for newcomers to diagnose and interpret the many surprises they encounter.

Information seeking and newcomer adjustment. At its core, information seeking maps onto three adjustment types. In their theoretical article on information seeking, Miller and Jablin (1991) developed a typology of information sought during organizational entry. These include referent information, which includes understanding what is needed to function on the job (role clarity); appraisal information, which includes information on how well the newcomer is able to function in relation to role requirements (self-efficacy); and relational information, which relates to the quality of relationships with organizational insiders (social acceptance). Table 1 summarizes how the types of information sought and indicators of adjustment overlap.

Measuring information seeking. E. W. Morrison (2002) noted in her review of the newcomer information-seeking literature that some researchers have used global versus different types of measures, which makes comparisons across studies challenging. Some of the ways that information-seeking measures vary include the degree to which they address information acquisition (e.g., amount of information gathered), information types (e.g., referent, appraisal, and relational), and measurement approaches (e.g., composite or facet measurement). To examine these different measurement approaches, we studied the relationship between information seeking and outcomes and explored, using moderation analysis, whether results differed when analyses were conducted on facets and on aggregate measures.

Organizational socialization tactics. Socialization tactics are organizational approaches to information dissemination to facilitate adjustment in new roles. Van Maanen and Schein (1979) suggested that organizations could be differentiated on the basis of how they approach newcomer socialization on at least six dimensions. Even though they did not propose that the six dimensions represented all of the ways in which organizations differ in their approaches to socialization, the framework has motivated several subsequent studies.
The first aspect on which organizations differ is whether socialization practices are collective versus individual. Under the collective approach, newcomers go through common experiences as part of a group, whereas under the individual approach, newcomers accumulate unique experiences separate from other newcomers. Second, socialization tactics can be formal or informal. Formal tactics involve newcomers who are segregated from others and trained off the job, whereas informal tactics involve little separation between newcomers and existing employees. Third, socialization experiences can be sequential or random. Under sequential, newcomers know what phases they need to go through, whereas under random, the progression is more ambiguous. Fourth, fixed or variable socialization tactics involve having a timetable of when the socialization process is complete as opposed to having no specific timetable. Fifth, serial or disjunctive tactics refer to whether the person is socialized with the help of insiders or without the help of a role model. Finally, investiture versus divestiture tactics refer to whether newcomers receive feedback from insiders that affirms or disaffirms their identity.

A review of the literature indicates that researchers tend to draw from uncertainty reduction theory to explain the link between socialization tactics, adjustment, and outcomes. Saks and Ashforth (1997a) suggested that the purpose of tactics is to reduce the degree of uncertainty experienced during early socialization. Tactics shape the type of information newcomers receive, the source of this information, and the ease of getting information. As Jones (1986) and Allen (2006) proposed, socialization tactics should reduce uncertainty, which should reduce ambiguity for newcomers, leading to more positive attitudes and facilitating adjustment.

Organizational socialization tactics and newcomer adjustment. Jones (1986) proposed that the six tactics could be classified as content (collective, formal), context (sequential, fixed), and social (serial, investiture) aspects of socialization. This higher order classification has received scant attention. In one study that examined the relationship of content, context, and tactics with personorganization fit, Cable and Parsons (2001) found that these three dimensions were differentially related to outcomes. Their findings suggest the value of examining the differential relations between socialization dimensions and outcomes. Despite the theoretical rationale for expecting different tactics to relate differentially to outcomes, researchers have tended not to make differential predictions.

The three aspects of socialization tactics map onto the three aspects of newcomer adjustment (see Table 1). Specifically, content tactics address whether newcomers are trained off the job, where performance consequences are minimized, and prepared for their new roles in a way that is nonthreatening. When dangers of the new role are removed and newcomers can practice their roles without fear of failure, their confidence should increase. Thus, content tactics should be positively related to self-efficacy. Context tactics reflect whether newcomers have a fixed timetable and whether they know the stages they need to progress through and, therefore, should contribute to role clarity. Finally, social tactics encourage organizations to provide mentoring and positive feedback to newcomers, leading to greater social acceptance.

Measuring organizational socialization tactics. It is important to examine whether future research should study the six socialization tactics separately or as one dimension. An argument against aggregation is whether there is agreement on the classification of 
different tactics as institutionalized as opposed to individualized. Specifically, some evidence suggests that not all of the dimensions fit well with this aggregated conceptualization. For example, it is not clear whether the investiture dimension behaves as the other institutionalized tactics. Jones (1986) classified investiture as an institutionalized tactic. Others followed suit and found positive relations between investiture and other institutionalized tactics (e.g., Allen \& Meyer, 1990; Ashforth \& Saks, 1996). However, Saks and Ashforth (1997b) found negative correlations between investiture and some other institutionalized tactics, and Laker and Steffy (1995) classified investiture as an individualized tactic. We agree with Saks and Ashforth (1997a) that, given the conflicting treatment of investiture in the field, it is important to continue to examine whether aggregation of the different tactics is warranted. To examine the validity of the single continuum, we studied the relationship between each tactic and the different outcomes and conducted moderation tests to determine whether results differed when analyses were conducted on facets or on aggregate measures.

\section{Outcomes of Newcomer Adjustment}

Newcomer adjustment has been associated with outcomes such as performance, job attitudes, and retention (Bauer et al., 1998). The relationships among newcomer adjustment and the outcomes in Figure 1 have been studied to varying degrees, and adjustment is often related to socialization outcomes. However, the nature of these relationships is unclear because of conflicting findings across studies and a lack of individual studies that included the full set of outcomes.

Performance. We expected newcomer adjustment to relate to performance. Employees who are clear about role expectations are more likely to perform well, and those who believe they can accomplish their tasks tend to have greater goal accomplishment. Employees who are socially accepted by peers may perform at higher levels, given that the relationships they form with their peers may serve as social capital that facilitates their job performance (Bauer \& Green, 1994). Thus, we expected positive relations between adjustment and job performance.

Job attitudes. Job satisfaction, organizational commitment, and intentions to remain are three of the most studied outcomes of socialization. We predicted that newcomer adjustment was related to all three attitudes. Role ambiguity is a source of dissatisfaction because it is associated with high levels of stress and burnout. Employees who are not clear about their roles may be less satisfied and committed to the organization and more likely to leave. In addition, research has linked uncertainty to lower job satisfaction (e.g., Louis, 1980). Similarly, employees who have high selfefficacy will feel confident that they can achieve key aspects of their jobs and be more satisfied, committed to the organization, and less likely to want to leave. Finally, receiving social support on the job is important for job attitudes (Fisher, 1985; Louis, Posner, \& Powell, 1983).

Turnover. Employees who adjust to their new roles by understanding role demands, feeling capable of performing tasks, and establishing effective relationships with peers will have a strong attachment to the organization that will prevent them from leaving their jobs. When newcomers successfully adjust to their roles and work environment, they should be less likely to quit. Wanous (1980) found a link between uncertainty and premature turnover.

\section{Potential Methodological Moderators of Newcomer Adjustment}

Data collection design (longitudinal vs. cross-sectional). We explicitly considered data collection design (longitudinal vs. crosssectional) as a moderator of observed relationships. Key variables in the socialization process can be measured at the same time or on different occasions. Given the tendency for correlations over longer time periods to decline in magnitude, it is important to explore which correlations among socialization variables are most influenced by the length of time between measurements. Although many studies in the field of organizational socialization are now longitudinal, cross-sectional studies still exist. In addition, even when studies gather data across time, many of the individual relationships reported are, in fact, cross-sectional.

Transition from school versus work. As socialization is a process of uncertainty reduction, we determined that it is important to account for the effects of sampling issues in the analyses. Not all newcomers deal with the same degree of uncertainty as they enter organizations. We proposed that newcomers transitioning from school to work face more drastic transitions and greater challenges than those transitioning from one job to another job (Ashforth, 2001). On the other hand, newcomers who are transitioning from one organization to another may have established ways of accomplishing their roles and may thus experience more difficulty in accepting "new" ways. Therefore, we examined the moderating effects of the type of work transition on the relationships.

Measurement of information seeking and organizational socialization tactics. Some studies report information seeking and tactics at the facet level (e.g., Allen \& Meyer, 1990; Ashforth \& Saks, 1996), whereas others report only composite measures (e.g., Bravo, Peiro, Rodriguez, \& Whitely, 2003; Mignerey, Rubin, \& Gorden, 1995). It is unclear how these different measurement approaches affect the conclusions drawn from these studies. For example, researchers have measured tactics in three ways. First has been to conduct analyses and report findings for all six dimensions (e.g., Allen \& Meyer, 1990; Ashforth \& Saks, 1996). Second has been to use the three-dimensional approach, which aggregates tactics into content, context, and social dimensions (e.g., Allen, 2006; Cable \& Parsons, 2001). Third, Jones (1986) referred to tactics on the formal side of the continuum as "institutional tactics" and tactics on the less formal side as "individualized tactics." Following this classification, several researchers combined all six tactics as institutionalized and individualized tactics (e.g., Bravo et al., 2003; Mignerey et al., 1995). It is unclear whether measurement affects findings.

\section{Method}

\section{Criteria for Inclusion}

In choosing studies for this meta-analysis, we had three inclusion criteria. First, we focused on studies of organizational newcomers, which we defined as those who had been on a new job in a new company for 13 months or less. Therefore, we excluded studies examining transferees. Similarly, we did not include studies of expatriates because they are adjusting to new cultures as well as to new organizations (Bauer \& Taylor, 2001) and because a recent meta-analysis has been conducted on expatriate adjustment 
(Bhuasskar-Shrinivas, Harrison, Shaffer, \& Luk, 2005). Second, we chose to focus on organizational socialization, not occupational socialization. Organizational and occupational socialization are different types of adjustment. For example, learning to be a nurse is different from learning to work at a new hospital as a nurse. Third, we included studies that measured at least two of the variables presented in Figure 1 and also reported correlation coefficients.

\section{Literature Search}

We obtained both published and unpublished empirical studies through a variety of means. First, to locate relevant journal articles, we conducted a computerized search using PsycINFO from 1872 until January 1, 2006, using the following keywords: "newcomer," "organizational socialization," "employee socialization," "feedback seeking" + "socialization," and "information seeking" + "socialization." Next, we searched the conference programs from 2000 through 2005 for the annual meetings of the Society of Industrial and Organizational Psychology and the national meetings of the Academy of Management for articles including the keywords "socialization" or "newcomer." We searched the digital dissertation Web site (http://wwwlib.umi.com) using the key word "socialization" from 2000 through 2005. Talya N. Bauer read the abstracts to determine inclusion. Finally, we contacted 10 experts who have published articles on organizational socialization. We sent them the list of articles we had considered and asked them to note or share any additional articles (published, in press, or working papers).

\section{Coding for Meta-Analysis}

Four subject matter experts (SMEs) coded the variables included in Figure 1. A team of two SMEs examined all of the studies for all variables except information seeking and organizational socialization tactics. A third SME created composite variables for these remaining two constructs and coded correlations. Following this, a fourth SME recoded a random sample of $20 \%$ of all of the studies. The initial average interrater agreement for the SMEs was $95 \%$. Differences in coding were discussed to consensus. Articles were then recoded as needed.

In a number of studies, socialization tactics and information and feedback seeking were measured with several items on multiple dimensions. In these cases, more than one effect size was available for inclusion in the meta-analysis. When the correlations were available, we combined these variables into composite variables and then based the included effect size on the correlations on the basis of the composite variables (Hunter \& Schmidt, 1990). When all the necessary correlations were unavailable for creating the composite, we randomly selected one of the possible effect sizes for inclusion (Lipsey \& Wilson, 2001; Rosenthal \& Rubin, 1986).

\section{Sample Description}

On the basis of the literature review, we identified 70 unique samples $(N=12,279)$ that met our inclusion criteria. Of those studies, $83 \%$ were longitudinal. The mean number of data collection periods for the longitudinal studies was $2.90(S D=.94)$. The average time of the first data collection was 1 week postentry. The average time of the second data collection was 5.5 months postentry, ranging from 1 to 12 months, with almost all of the studies gathering data by 6 months. The average time between Time 1 and Time 2 was 4.42 months $(S D=3.43)$ for the studies that had two or more data collections. Participants were mostly White $(84 \%)$ and most held at least an undergraduate degree $(86 \%)$.

\section{Results}

\section{Meta-Analysis of Antecedents and Outcomes of Newcomer Adjustment}

Our first goal in this study was to integrate past studies of socialization into a model of antecedents and outcomes of adjustment and test this model using meta-analysis and path modeling. Table 2 presents the results of the meta-analytic combination of correlations for the $10 \mathrm{key}$ socialization variables under study. The total sample sizes of the 45 meta-analytic correlations ranged from 272 to 4,027 participants.

Descriptively, only 2 of the 45 correlations were smaller than .10 (in absolute value), suggesting a less-than-small correlation by Cohen's (1988) guidelines. Inferentially, one of these two correlations did not differ significantly from zero on the basis of the $Z$ test (Rosenthal, 1991). Although all but one of the correlations differed significantly from zero, there is considerable uncertainty in the plausible range of the population correlations of interest as indexed by many of the $95 \%$ confidence intervals. In a fixedeffects analysis, the width of the confidence interval is determined primarily by a function of the cumulative sample size. Fail-safe $K$ refers to the estimated number of studies with an average effect size of zero that would be needed to bring the obtained effect size to less than a criterion level. The Fail-safe $K$ for the 43 correlations exceeding I.10I was a median of 10 studies.

To further test the relationships among the 10 variables, we conducted a path analysis using a structural equation modeling approach (cf. J. Z. Carr, Schmidt, Ford, \& DeShon, 2003; Cheung \& Chan, 2005), using the meta-analytic correlations in Table 2 as input. We specified the path model based on Figure 1, allowing all variables to relate to all other variables. Most of the partial associations among variables were statistically significant, and the parameter estimates were in the expected direction. Eleven of the partial associations were not statistically significant, implying that the effect of a variable on the other is at best indirect in nature (e.g., role clarity was not significantly related to turnover, controlling for the other variables).

Omitting these 11 nonsignificant paths resulted in a model that fit the data well: $\chi^{2}(11, N=877)=13.11, p=.29$; goodnessof-fit index $=.99$; comparative fit index $=.99$; root-mean-square error of approximation $=.01$. Figure 2 presents the results of this path analysis. In terms of the antecedents of newcomer adjustment, we found that information seeking was positively related to role clarity and social acceptance, but it was not significantly related to self-efficacy. Socialization tactics were positively related to all three adjustment variables. We also found that role clarity was related to all of the outcomes except turnover. Self-efficacy was related to all outcomes except organizational commitment and job satisfaction. Finally, social acceptance was related to all five of the outcomes studied. 
Table 2

Descriptive and Inferential Statistics From the Meta-Analytic Synthesis of Correlations Among All Variables From Figure 1

\begin{tabular}{|c|c|c|c|c|c|c|}
\hline Variable & $\bar{r}$ & $95 \% \mathrm{CI}$ & $k$ studies & $N$ & $S D$ & Fail-safe $K$ \\
\hline \multicolumn{7}{|l|}{ Information seeking } \\
\hline Socialization tactics & $.22^{*}$ & $.14, .30$ & 3 & 553 & .11 & 4 \\
\hline Role clarity & $.17^{*}$ & $.13, .21$ & 10 & 2,549 & .09 & 7 \\
\hline Self-efficacy & $.14^{*}$ & $.05, .23$ & 3 & 450 & .06 & 1 \\
\hline Social acceptance & $.16^{*}$ & $.08, .23$ & 6 & 697 & .10 & 4 \\
\hline Job performance & $.08^{*}$ & $.03, .14$ & 10 & 1,260 & $.18^{*}$ & - \\
\hline Job satisfaction & $.20^{*}$ & $.15, .24$ & 13 & 1,809 & $.19^{*}$ & 13 \\
\hline Organizational commitment & $.21^{*}$ & $.16, .26$ & 9 & 1,438 & $.16^{*}$ & 10 \\
\hline Intentions to remain & $.15^{*}$ & $.10, .20$ & 10 & 1,458 & $.17^{*}$ & 5 \\
\hline Turnover & -.08 & $-.18, .03$ & 3 & 369 & .13 & - \\
\hline \multicolumn{7}{|l|}{ Socialization tactics } \\
\hline Role clarity & $.27^{*}$ & $.23, .31$ & 7 & 1,954 & $.22^{*}$ & 12 \\
\hline Self-efficacy & $.42^{*}$ & $.33, .51$ & 2 & 314 & $.16^{*}$ & 6 \\
\hline Social acceptance & $.19^{*}$ & $.14, .24$ & 4 & 1,459 & .12 & 4 \\
\hline Job performance & $.15^{*}$ & $.08, .22$ & 5 & 715 & $.26^{*}$ & 3 \\
\hline Job satisfaction & $.43^{*}$ & $.38, .48$ & 7 & 962 & $.13^{*}$ & 23 \\
\hline Organizational commitment & $.15^{*}$ & $.10, .19$ & 8 & 1,884 & $.31^{*}$ & 4 \\
\hline Intentions to remain & $.34^{*}$ & $.28, .40$ & 5 & 809 & .10 & 12 \\
\hline Turnover & $-.14^{*}$ & $-.19,-.08$ & 4 & 1,466 & .02 & 2 \\
\hline \multicolumn{7}{|l|}{ Role clarity } \\
\hline Self-efficacy & $.45^{*}$ & $.40, .49$ & 5 & 1,239 & $.15^{*}$ & 18 \\
\hline Social acceptance & $.23^{*}$ & $.20, .27$ & 13 & 3,255 & $.21^{*}$ & 17 \\
\hline Job performance & $.29^{*}$ & $.25, .33$ & 7 & 1,958 & $.09^{*}$ & 13 \\
\hline Job satisfaction & $.32^{*}$ & $.29, .35$ & 22 & 3,395 & $.13^{*}$ & 48 \\
\hline Organizational commitment & $.29^{*}$ & $.26, .33$ & 14 & 3,138 & $.10^{*}$ & 27 \\
\hline Intentions to remain & $.23^{*}$ & $.19, .27$ & 14 & 2,239 & $.15^{*}$ & 18 \\
\hline Turnover & $-.11^{*}$ & $-.22,-.00$ & 4 & 315 & .07 & 1 \\
\hline \multicolumn{7}{|l|}{ Self-efficacy } \\
\hline Social acceptance & $.28^{*}$ & $.21, .35$ & 4 & 872 & .06 & 7 \\
\hline Job performance & $.35^{*}$ & $.28, .41$ & 6 & 724 & $.23^{*}$ & 15 \\
\hline Job satisfaction & $.28^{*}$ & $.22, .34$ & 8 & 1,162 & $.17^{*}$ & 11 \\
\hline Organizational commitment & $.20^{*}$ & $.16, .25$ & 8 & 1,620 & $.14^{*}$ & 8 \\
\hline Intentions to remain & $.15^{*}$ & $.08, .21$ & 7 & 841 & $.13^{*}$ & 4 \\
\hline Turnover & $-.16^{*}$ & $-.27,-.04$ & 2 & 272 & .05 & 1 \\
\hline \multicolumn{7}{|l|}{ Social acceptance } \\
\hline Job performance & $.21^{*}$ & $.11, .29$ & 4 & 455 & $.23^{*}$ & 4 \\
\hline Job satisfaction & $.33^{*}$ & .29 .37 & 15 & 1,849 & $.16^{*}$ & 35 \\
\hline Organizational commitment & $.35^{*}$ & $.31, .39$ & 10 & 1,965 & $.11^{*}$ & 25 \\
\hline Intentions to remain & $.24^{*}$ & $.19, .30$ & 9 & 1,235 & .14 & 13 \\
\hline Turnover & $-.16^{*}$ & $-.24,-.08$ & 4 & 626 & .09 & 2 \\
\hline \multicolumn{7}{|l|}{ Job performance } \\
\hline Job satisfaction & $.21^{*}$ & $.17, .26$ & 13 & 1,892 & $.21^{*}$ & 14 \\
\hline Organizational commitment & $.20^{*}$ & $.15, .24$ & 11 & 1,694 & $.16^{*}$ & 11 \\
\hline Intentions to remain & $.12^{*}$ & $.01, .23$ & 4 & 327 & .10 & 1 \\
\hline Turnover & $-.19^{*}$ & $-.28,-.08$ & 4 & 368 & .06 & 4 \\
\hline \multicolumn{7}{|l|}{ Job satisfaction } \\
\hline Organizational commitment & $.58^{*}$ & $.56, .60$ & 26 & 4,027 & $.19^{*}$ & 125 \\
\hline Intentions to remain & $.63^{*}$ & $.60, .64$ & 25 & 3,587 & $.20^{*}$ & 133 \\
\hline Turnover & $-.10^{*}$ & $-.15,-.04$ & 11 & 1,291 & $.27^{*}$ & 1 \\
\hline \multicolumn{7}{|l|}{ Organizational commitment } \\
\hline Intentions to remain & $.54^{*}$ & $.52, .57$ & 17 & 2,682 & $.24^{*}$ & 75 \\
\hline Turnover & $-.16^{*}$ & $-.21,-.12$ & 8 & 1,740 & $.17^{*}$ & 5 \\
\hline \multicolumn{7}{|l|}{ Intentions to remain } \\
\hline Turnover & $-.22^{*}$ & $-.15,-.28$ & 8 & 856 & $.13^{*}$ & 10 \\
\hline
\end{tabular}

Note. Organizational socialization tactics are coded so that the higher end of the continuum represents institutionalized tactics as categorized by Jones (1986). Dashes indicate that a correlation was already less than I.10l. $\bar{r}=$ weighted average correlation; $\mathrm{CI}=$ confidence interval; $S D=$ standard deviation of observed effect sizes.

${ }^{*} p<.05$.

In terms of mediation, information seeking had only one direct effect on the outcomes (for organizational commitment). The other relationships were fully mediated by adjustment. Thus, the relationship between information seeking and socialization outcomes appears to be mostly indirect. On the other hand, socialization tactics had direct effects on job satisfaction and intentions to remain, which indicates that adjustment partially mediates these relationships. 


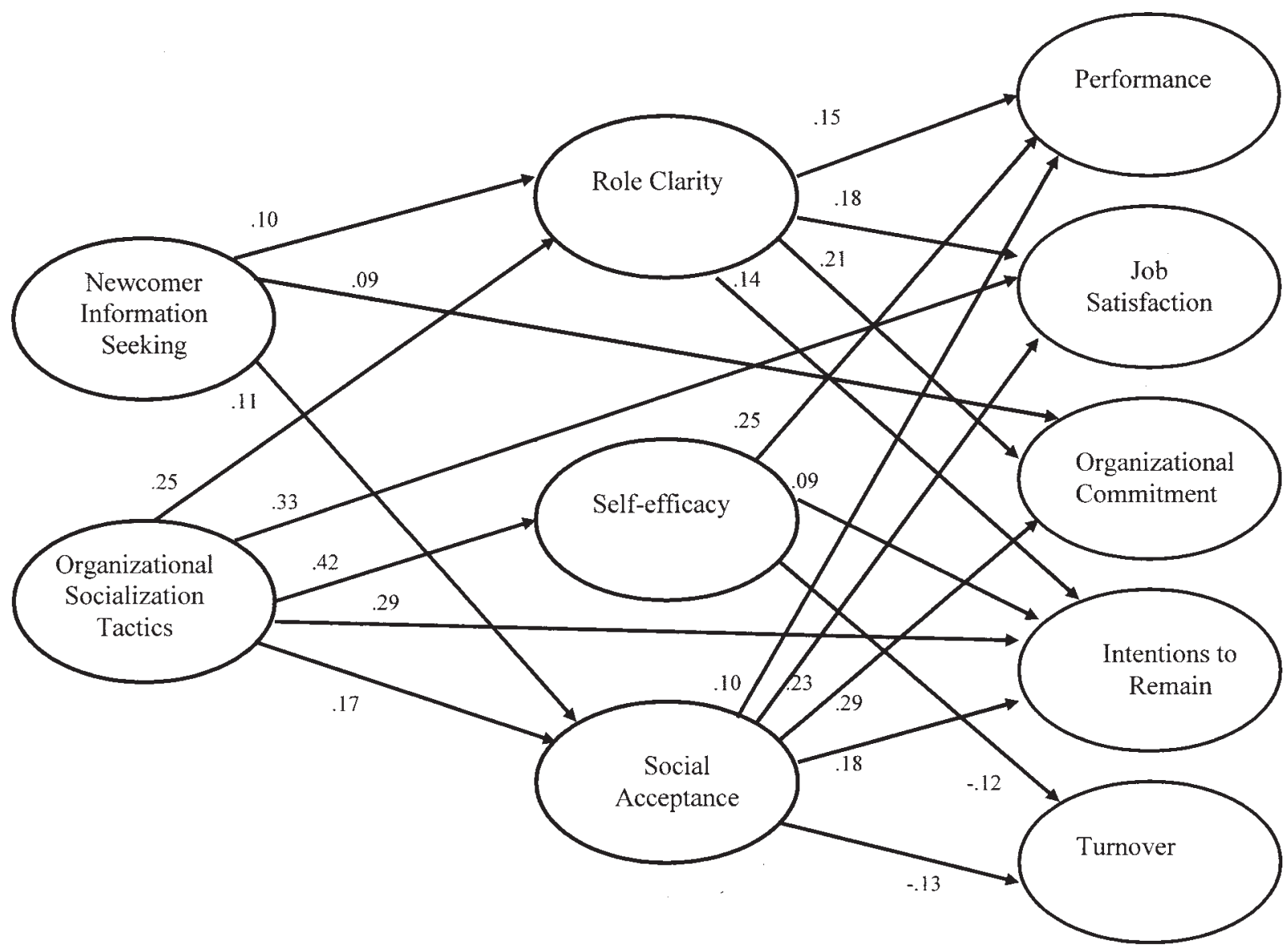

Figure 2. Standardized parameter estimates from the final socialization process model. For clarity of presentation, correlations among variables within wave and all nonsignificant correlations across waves have been omitted. All parameter estimates are significant at the .05 level. For socialization tactics, high scores indicate institutionalized socialization (as categorized by Jones, 1986).

\section{Relationships With Facets of Information Seeking and Socialization Tactics}

Information seeking and socialization tactics are constructs consisting of several facets. Our results showed that the intercorrelations among the information-seeking tactics were as follows $(K=$ 8). Appraisal information seeking was correlated with both referent and social information seeking at .49. Referent and social information seeking were correlated at .32. For tactics, the range of intercorrelations was between -.11 and .57 , with an average of .38 (see Table 3). The meta-analytic correlations presented in Table 4 provide the correlations among these variables measured at the facet level only, newcomer adjustment, and the five outcome variables.

Overall, the correlations between facets of information seeking and socialization tactics and the newcomer adjustment variables were positive. For relationships between the facets of information seeking and newcomer adjustment, the referent and appraisal information facets were significantly related with role clarity and social acceptance. In contrast, the relational information facet of information seeking was not significantly related to any of the adjustment dimensions. For the relationships between the facets of socialization tactics and newcomer adjustment, all six facets were significantly correlated with role clarity, whereas all but the formal facet were significantly correlated with self-efficacy, and only the fixed, serial, and investiture facets were significantly correlated with social acceptance.

We also examined the correlations between facets of information seeking and socialization tactics with socialization outcomes.

Table 3

Intercorrelations Among Facets of Organizational Socialization Tactics

\begin{tabular}{lrrrrrr}
\hline \multicolumn{1}{c}{ Tactic } & 1 & 2 & 3 & 4 & 5 & 6 \\
\hline 1. Collective & - & & & & & \\
2. Formal & .44 & - & & & & \\
3. Sequential & .45 & .55 & - & & & \\
4. Fixed & .39 & .46 & .57 & - & & \\
5. Serial & .41 & .43 & .53 & .56 & - & \\
6. Investiture & .10 & -.11 & .02 & .12 & .22 & - \\
\hline
\end{tabular}

Note. $K=8$. Organizational socialization tactics are coded so that the higher end of the continuum represents institutionalized tactics as categorized by Jones (1986). 
Table 4

Correlations Between Information Seeking and Organizational Socialization Tactics With Newcomer Adjustment and Socialization Outcomes

\begin{tabular}{|c|c|c|c|c|c|c|c|c|}
\hline \multirow[b]{2}{*}{ Variable } & \multicolumn{4}{|c|}{ Information seeking (adapted from Miller \& Jablin, 1991) } & \multicolumn{4}{|c|}{$\begin{array}{l}\text { Organizational socialization tactic (adapted } \\
\text { from Jones, 1986) }\end{array}$} \\
\hline & Category & $r$ & $K$ & $N$ & Category & $r$ & $K$ & $N$ \\
\hline \multicolumn{9}{|c|}{ Adjustment } \\
\hline \multirow[t]{6}{*}{ Role clarity } & Referent information & $.11^{*}$ & 7 & 1,198 & Collective & $.25^{*}$ & 3 & 327 \\
\hline & & & & & Formal & $.20^{*}$ & 3 & 327 \\
\hline & Appraisal information & $.17^{*}$ & 5 & 570 & Sequential & $.49^{*}$ & 4 & 500 \\
\hline & & & & & Fixed & $.46^{*}$ & 4 & 500 \\
\hline & Relational information & .06 & 3 & 339 & Serial & $.50^{*}$ & 4 & 500 \\
\hline & & & & & Investiture & $.45^{*}$ & 3 & 409 \\
\hline \multirow[t]{6}{*}{ Self-efficacy } & Referent information & $.14^{*}$ & 3 & 450 & Collective & $.22^{*}$ & 2 & 314 \\
\hline & & & & & Formal & .03 & 1 & 154 \\
\hline & Appraisal information & .16 & 1 & 135 & Sequential & $.24^{*}$ & 2 & 314 \\
\hline & & & & & Fixed & $.29^{*}$ & 2 & 314 \\
\hline & Relational information & .07 & 1 & 202 & Serial & $.31^{*}$ & 2 & 314 \\
\hline & & & & & Investiture & $.40^{*}$ & 2 & 314 \\
\hline \multirow[t]{5}{*}{ Social acceptance } & Referent information & $.16^{*}$ & 3 & 445 & Collective & & & \\
\hline & Appraisal information & $.20^{*}$ & 2 & 240 & $\begin{array}{l}\text { Formal } \\
\text { Sequential }\end{array}$ & .09 & 1 & 85 \\
\hline & 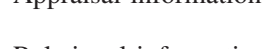 & & & & Fixed & $.22^{*}$ & 1 & 85 \\
\hline & Relational information & .07 & 3 & 399 & Serial & $.24^{*}$ & 1 & 85 \\
\hline & & & & & Investiture & $.42^{*}$ & 1 & 85 \\
\hline \multicolumn{9}{|c|}{ Socialization outcomes } \\
\hline \multirow[t]{6}{*}{ Performance } & Referent information & .05 & 4 & 733 & Collective & .03 & 3 & 467 \\
\hline & & & & & Formal & -.08 & 3 & 467 \\
\hline & Appraisal information & .10 & 2 & 206 & Sequential & $.13^{*}$ & 4 & 552 \\
\hline & & & & & Fixed & $.11^{*}$ & 4 & 552 \\
\hline & Relational information & .01 & 3 & 310 & Serial & $.13^{*}$ & 4 & 552 \\
\hline & & & & & Investiture & $.12^{*}$ & 4 & 552 \\
\hline \multirow[t]{6}{*}{ Job satisfaction } & Referent information & $.08^{*}$ & 7 & 1,138 & Collective & $.16^{*}$ & 5 & 731 \\
\hline & & & & & Formal & $.11^{*}$ & 4 & 569 \\
\hline & Appraisal information & $.18^{*}$ & 5 & 510 & Sequential & $.36^{*}$ & 5 & 731 \\
\hline & & & & & Fixed & $.34^{*}$ & 5 & 731 \\
\hline & Relational information & $.12^{*}$ & 6 & 715 & Serial & $.39^{*}$ & 5 & 731 \\
\hline & & & & & Investiture & $.37^{*}$ & 5 & 731 \\
\hline \multirow[t]{6}{*}{ Organizational commitment } & Referent information & .04 & 4 & 880 & Collective & $.13^{*}$ & 5 & 743 \\
\hline & & & & & Formal & -.01 & 5 & 672 \\
\hline & Appraisal information & $.15^{*}$ & 2 & 252 & Sequential & $.18^{*}$ & 6 & 834 \\
\hline & & & & & Fixed & $.15^{*}$ & 6 & 834 \\
\hline & Relational information & .06 & 3 & 457 & Serial & $.21^{*}$ & 6 & 834 \\
\hline & & & & & Investiture & $.40^{*}$ & 6 & 834 \\
\hline \multirow[t]{6}{*}{ Intentions to remain } & Referent information & $.07^{*}$ & 6 & 933 & Collective & $.12^{*}$ & 5 & 731 \\
\hline & & & & & Formal & $.19^{*}$ & 4 & 569 \\
\hline & Appraisal information & $.14^{*}$ & 5 & 510 & Sequential & $.26^{*}$ & 5 & 731 \\
\hline & & & & & Fixed & $.27^{*}$ & 5 & 731 \\
\hline & Relational information & $.14^{*}$ & 5 & 510 & Serial & $.28^{*}$ & 5 & 731 \\
\hline & & & & & Investiture & $.21^{*}$ & 5 & 731 \\
\hline \multirow[t]{6}{*}{ Turnover } & Referent information & .14 & 1 & 97 & Collective & .00 & 2 & 316 \\
\hline & & & & & Formal & -.06 & 1 & 154 \\
\hline & Appraisal information & .04 & 1 & 97 & Sequential & $-.12^{*}$ & 2 & 316 \\
\hline & & & & & Fixed & -.07 & 2 & 316 \\
\hline & Relational information & .11 & 1 & 97 & Serial & -.07 & 2 & 316 \\
\hline & & & & & Investiture & $-.10^{*}$ & 2 & 316 \\
\hline
\end{tabular}

Note. Content tactics are collective and formal, context tactics are sequential and fixed, and social tactics are serial and investiture. Tactics were coded so that higher numbers represent institutionalized tactics following the socialization tactic categorization by Jones (1986). Information seeking was categorized following Miller and Jablin (1991).

${ }^{*} p<.05$. 
With the exception of the facets of socialization tactics and turnover, the correlations were mostly positive in direction. All three facets of information seeking were significantly correlated with satisfaction and intentions to remain, only the appraisal facet was significantly correlated with organizational commitment, and none of the facets of information seeking were significantly correlated with performance or turnover. All six of the facets of socialization tactics were significantly correlated with satisfaction and intentions to remain. All facets, except for the formal facet, were significantly correlated with organizational commitment. All facets, except for formal and collective, were significantly correlated with performance. Only the sequential and investiture facets were significantly correlated with turnover.

\section{Moderator Analyses}

Our second goal was to understand how different methodological approaches have affected the literature. For the correlations noted in Table 2, we used Hedges and Olkin's (1985) $Q$ test to evaluate the homogeneity of each of the 45 unique effect size distributions. Of these, 30 showed significant variability across studies, suggesting that exploring moderators was warranted. We examined the impact of three socialization moderators on these effect size distributions.

Type of data collection (longitudinal vs. cross-sectional). Because socialization unfolds over time, we expected the magnitudes of the associations among socialization variables in Figure 1 to vary as a function of the time of the assessment of each construct. Thus, we conducted exploratory moderator analyses of the effect sizes to understand the influence of longitudinal versus crosssectional data collections on the effect sizes. Typically, the magnitude of a correlation decreases as the time between measurements increases (Nunnally \& Bernstein, 1994). Therefore, this was our expectation for the moderator analyses. We also were interested in seeing which relationships were susceptible to the effects of data collection type decisions.

Table 5 presents the results of these moderator analyses. Generally, larger correlations were found for variables assessed at the same time. The two cases in which the opposite was true (and the differences were statistically significant) were due to the inclusion in the analyses of relatively large studies with results that differed markedly from the other studies within that group. ${ }^{1}$ Removing these studies reversed the trend in correlations to the general pattern, but the difference between time of measurement was no longer statistically significant. Role clarity was more positively related to socialization tactics, performance, job satisfaction, organizational commitment, and intentions to remain when measured at the same time. Similarly, intention to remain was more strongly correlated with self-efficacy and social acceptance, job satisfaction was more strongly correlated with social acceptance, and organizational commitment was more strongly correlated with selfefficacy when measured at the same time.

Transitioning from school versus work. One important study feature in this literature is whether the data were collected on a sample of students or existing workers transitioning into a new organization. To explore whether the relationships between variables vary by sample type, we conducted a series of moderator analyses. The results are presented in Table 5. Self-efficacy was more positively related to intentions to remain and performance in school-to-work samples. Moreover, social acceptance was more positively related to performance in the school-to-work samples.

Composite versus facet measurement. Both information seeking and socialization tactics are constructs with nuanced underlying dimensions. Researchers studying relationships with these constructs may do so measuring the composite construct or facets of the construct. Our interest lay in whether and how this choice may moderate the relationships between these constructs and other variables of interest. Studies were coded as originally, using a composite- or facet-based measure of information seeking and socialization tactics. If a facet-based measure was used and the necessary correlations among facets and the variables of interest were available, we computed a composite correlation using a technique described by Nunnally and Bernstein (1994). ${ }^{2}$ The results are presented in Table 5.

\section{Discussion}

Overall, we found general support for the summary model presented in Figure 1. Consistent with Feldman (1981), role clarity, self-efficacy, and social acceptance emerged as three important indicators of newcomer adjustment. For the antecedents of adjustment, we found, using composite measures, that information seeking was significantly related to role clarity and social acceptance, whereas socialization tactics were related to all three adjustment types. This is consistent with the important role that information seeking plays in uncertainty reduction (Saks \& Ashforth, 1997a). Examining the facets of information seeking, referent and appraisal information were related to most of the adjustment indicators, but the relational facet was unrelated. We found that a majority of the tactics was related to all three types of adjustment, consistent with the proposed role of socialization tactics for newcomer uncertainty reduction (Allen, 2006; Jones, 1986). For the outcomes of adjustment, we found that social acceptance was related to all outcomes, self-efficacy was related to all of the outcomes except job satisfaction and organizational commitment, and role clarity was related to all of the outcomes except turnover.

\section{Moderators}

We found that data collection choices, sampling, and measurement matter. First, our tests of methodological moderators revealed some differences in terms of how socialization studies are conducted. Overall, $56 \%$ of the relationships examined were affected by data collection type. In general, the findings demonstrate that many of the relationships examined in this study were stronger when the data were collected cross-sectionally rather than longitudinally. Second, we found that sampling affected $26 \%$ of the relationships examined. It appears that for recent graduate sam-

\footnotetext{
${ }^{1}$ Please contact Talya N. Bauer for more specifics on these exceptions.

${ }^{2}$ To illustrate this method, consider the case of two constructs (e.g., $X$ and $Y$ ), each measured by one or more variables. Let $\mathbf{R}_{X X}$ and $\mathbf{R}_{Y Y}$ represent the within-construct correlation matrices, and let $\mathbf{R}_{X Y}$ represent the between-construct matrix of correlations. Of interest is the correlation between the composite variables for $X$ and $Y$. Nunnally and Bernstein (1994) and Hunter and Schmidt (1990) illustrate that this composite correlation can be computed as the ratio of the sum of the elements in $\mathbf{R}_{X Y}$ to the square root of the product of the sums in $\mathbf{R}_{X X}$ and $\mathbf{R}_{Y Y}$.
} 
Table 5

Moderation Analyses for Adjustment Examining Data Collection, Sample Studied, and Measurement

\begin{tabular}{|c|c|c|c|c|c|c|c|c|c|}
\hline \multirow[b]{3}{*}{ Relationship } & \multicolumn{9}{|c|}{ Moderator } \\
\hline & \multicolumn{3}{|c|}{$\begin{array}{l}\text { Longitudinal or cross- } \\
\text { sectional data collection }\end{array}$} & \multicolumn{3}{|c|}{$\begin{array}{l}\text { Work-to-work or school-to- } \\
\text { work sample }\end{array}$} & \multicolumn{3}{|c|}{$\begin{array}{l}\text { Composite or facet } \\
\text { measurement }\end{array}$} \\
\hline & $\begin{array}{l}\text { Level of } \\
\text { moderator }\end{array}$ & $\begin{array}{l}\text { Effect } \\
\text { size }\end{array}$ & $K$ & $\begin{array}{l}\text { Level of } \\
\text { moderator }\end{array}$ & $\begin{array}{l}\text { Effect } \\
\text { size }\end{array}$ & $K$ & $\begin{array}{l}\text { Level of } \\
\text { moderator }\end{array}$ & $\begin{array}{l}\text { Effect } \\
\text { size }\end{array}$ & $K$ \\
\hline \multirow{2}{*}{ Information seeking-Role clarity } & Same & $.15^{\mathrm{a}}$ & 7 & Student & .16 & 3 & Composite & .14 & 2 \\
\hline & Different & $.24^{\mathrm{b}}$ & 3 & Work & .23 & 6 & Facet & .21 & 8 \\
\hline \multirow[t]{2}{*}{ Information seeking-Self-efficacy } & Same & .16 & 2 & Student & .16 & 2 & Composite & .21 & 1 \\
\hline & Different & .10 & 1 & Work & .10 & 1 & Facet & .12 & 2 \\
\hline \multirow[t]{2}{*}{ Information seeking-Social acceptance } & Same & .17 & 5 & Student & .09 & 2 & Composite & $.28^{\mathrm{a}}$ & 1 \\
\hline & Different & .10 & 1 & Work & .20 & 4 & Facet & $.11^{\mathrm{b}}$ & 5 \\
\hline \multirow{2}{*}{ Socialization tactics-Role clarity } & Same & $.48^{\mathrm{a}}$ & 4 & Student & $.42^{\mathrm{a}}$ & 2 & Composite & $.14^{\mathrm{a}}$ & 3 \\
\hline & Different & $.18^{\mathrm{b}}$ & 3 & Work & $.49^{\mathrm{b}}$ & 4 & Facet & $.46^{\mathrm{b}}$ & 4 \\
\hline \multirow{2}{*}{ Socialization tactics-Self-efficacy } & Same & .43 & 2 & Student & $.38^{\mathrm{a}}$ & 1 & Composite & & 0 \\
\hline & Different & & 0 & Work & $.54^{\mathrm{b}}$ & 1 & Facet & .43 & 2 \\
\hline \multirow[t]{2}{*}{ Socialization tactics-Social acceptance } & Same & .24 & 3 & Student & & 0 & Composite & .18 & 3 \\
\hline & Different & .18 & 1 & Work & .24 & 3 & Facet & .33 & 1 \\
\hline \multirow[t]{2}{*}{ Role clarity_Job performance } & Same & $.18^{\mathrm{a}}$ & 3 & Student & .27 & 3 & & & \\
\hline & Different & $.34^{\mathrm{b}}$ & 4 & Work & .30 & 4 & & & \\
\hline \multirow[t]{2}{*}{ Role clarity_Job satisfaction } & Same & $.35^{\mathrm{a}}$ & 15 & Student & .33 & 9 & & & \\
\hline & Different & $.26^{\mathrm{b}}$ & 7 & Work & .31 & 13 & & & \\
\hline \multirow{2}{*}{ Role clarity_Organizational commitment } & Same & $.33^{\mathrm{a}}$ & 8 & Student & .27 & 8 & & & \\
\hline & Different & $.25^{\mathrm{b}}$ & 6 & Work & .31 & 5 & & & \\
\hline \multirow[t]{2}{*}{ Role clarity-Intentions to remain } & Same & $.31^{\mathrm{a}}$ & 9 & Student & .21 & 6 & & & \\
\hline & Different & $.13^{\mathrm{b}}$ & 5 & Work & .25 & 8 & & & \\
\hline \multirow[t]{2}{*}{ Role clarity-Turnover } & Same & & 0 & Student & & 0 & & & \\
\hline & Different & -.11 & 4 & Work & -.11 & 4 & & & \\
\hline \multirow{2}{*}{ Self-efficacy_Job performance } & Same & .48 & 1 & Student & $.40^{\mathrm{a}}$ & 5 & & & \\
\hline & Different & .32 & 5 & Work & $.01^{\mathrm{b}}$ & 1 & & & \\
\hline \multirow[t]{2}{*}{ Self-efficacy_Job satisfaction } & Same & .30 & 2 & Student & .25 & 4 & & & \\
\hline & Different & .19 & 5 & Work & .17 & 3 & & & \\
\hline \multirow[t]{2}{*}{ Self-efficacy_Organizational commitment } & Same & $.30^{\mathrm{a}}$ & 2 & Student & .21 & 5 & & & \\
\hline & Different & $.14^{\mathrm{b}}$ & 5 & Work & .13 & 2 & & & \\
\hline \multirow[t]{2}{*}{ Self-efficacy-Intentions to remain } & Same & $.20^{\mathrm{a}}$ & 3 & Student & $.20^{\mathrm{a}}$ & 3 & & & \\
\hline & Different & $.04^{\mathrm{b}}$ & 3 & Work & $.04^{\mathrm{b}}$ & 3 & & & \\
\hline \multirow[t]{2}{*}{ Self-efficacy_-Turnover } & Same & -.13 & 1 & Student & -.20 & 1 & & & \\
\hline & Different & -.20 & 1 & Work & -.13 & 1 & & & \\
\hline \multirow{2}{*}{ Social acceptance-Job performance } & Same & .16 & 1 & Student & $.30^{\mathrm{a}}$ & 2 & & & \\
\hline & Different & .23 & 3 & Work & $.11^{\mathrm{b}}$ & 2 & & & \\
\hline Social acceptance-Job satisfaction & Same & $.37^{\mathrm{a}}$ & 7 & Student & .34 & 5 & & & \\
\hline & Different & $.27^{\mathrm{b}}$ & 8 & Work & .32 & 10 & & & \\
\hline Social acceptance-Organizational commitment & Same & .39 & 4 & Student & .37 & 6 & & & \\
\hline & Different & .31 & 6 & Work & .32 & 4 & & & \\
\hline Social acceptance-Intentions to remain & Same & $.28^{\mathrm{a}}$ & 4 & Student & .26 & 6 & & & \\
\hline & Different & $.15^{\mathrm{b}}$ & 5 & Work & .23 & 5 & & & \\
\hline Social acceptance-Turnover & Same & & 0 & Student & -.20 & 2 & & & \\
\hline & Different & -.16 & 4 & Work & -.08 & 2 & & & \\
\hline
\end{tabular}

${ }^{\mathrm{a}, \mathrm{b}}$ Correlations are significantly different from each other at the $p<.05$ level.

ples, self-efficacy is a stronger predictor of job performance and intentions to remain. Furthermore, social acceptance is more strongly related to job performance in school-to-work samples. Finally, in terms of measurement at the facet versus the composite level, we found that a total of $40 \%$ of the relationships differed. The correlation between information seeking and social acceptance was stronger when a composite rather than a facet measure was used. In contrast, for socialization tactics, the correlation with role clarity was stronger with a facet approach.

We also were interested in examining the differential treatment of socialization tactics in the literature. We were curious to see whether classifying the six socialization tactics as institutionalized or individualized was warranted. For this purpose, we examined the correlations between the six tactics and newcomer adjustment and the outcomes. In most cases, the correlations between the tactics at the institutionalized end of the continuum were positively and significantly correlated with newcomer adjustment and the outcomes. Therefore, we did not find strong evidence that the classification of some tactics was incorrect. In addition, the moderator analysis showed that the relationship between tactics and role clarity was stronger when facets, as opposed to a composite measure, were used. This indicates that by collapsing different facets, we may lose important information and underestimate the relationship between information seeking and newcomer 
adjustment. However, for information seeking, we found the opposite.

\section{Potential Implications}

No single study has examined all of the relationships within Figure 1 at once. Meta-analysis coupled with path modeling allowed us to conduct such a study. We found strong support for the antecedent-adjustment and adjustment-outcome relationships, even when controlling for the other relationships. A key finding is that newcomer adjustment mediates (at least partially) the information seeking-outcome and tactics-outcome relationships. Therefore, to the degree that future researchers are interested in understanding the mechanisms of newcomer adjustment, these constructs (or other indicators of adjustment) should be included. Organizations should consider the types of adjustment (role clarity, self-efficacy, and social acceptance) as key indicators of newcomer socialization. To the degree that they can facilitate newcomers in achieving higher levels of each of these, they should see better job attitudes and performance. Although turnover has many potential antecedents, more successful adjustment appears to help increase intentions to remain and decrease turnover.

Several implications emerged from our moderator analyses. For example, it appears that role clarity is the adjustment indicator that is most susceptible to differences in the time of measurement. Role clarity was more positively related to socialization tactics, intentions to remain, job satisfaction, and organizational commitment when measured at the same time as opposed to longitudinally. When role clarity is of interest, researchers should make sure to consider data collection timing carefully. Gathering role clarity at the same time as attitudinal outcomes may inflate the relationship more severely than for other types of adjustment.

In terms of sampling, we found that different adjustment indicators became more salient for those who were transitioning from school to work. For example, social acceptance was more positively related to performance for these types of newcomers than for those moving from one job to another. Researchers should consider the salience of different adjustment and outcome variables given the nature of their samples.

Table 1 summarizes a new heuristic for integrating newcomer adjustment, information seeking, and tactics. However, we found limited support for a strict interpretation of Table 1. Uncertainty reduction theory (Berger, 1979) makes intuitive sense for the study of newcomer adjustment, but it has yet to be explicitly examined. We suggest that additional studies be conducted using this framework. However, we found that appraisal information was the most important of the three information types proposed by Miller and Jablin (1991) in terms of newcomer adjustment. This makes sense as the socialization process reflects learning the ropes, and gathering information about one's performance can facilitate that learning.

In terms of measuring information seeking, researchers need to carefully consider the goals of their studies. If their goal is to gather a general impression about the outcomes of socialization, then a composite measure makes sense. If, however, they are interested in understanding differential predictions, then they need to gather and report facet data, noting that this approach dampens the strength of the observed relationships. For tactics, using composite measures may sometimes weaken the observed relation- ships, so it is possible to underestimate the relationships among tactics and adjustment. We recommend that researchers gather information at the facet level and report both facet and composite measures in their correlation matrices to allow future metaanalyses to compare these studies more easily.

Because we found appraisal information to be the strongest predictor of newcomer adjustment, newcomers should consider seeking information regarding how well they are doing in their jobs and what else they can do to increase their level of success on the job. Similarly, because social tactics tended to have the strongest correlation with newcomer adjustment and socialization outcomes, organizations may consider giving employees feedback affirming their role as insiders and assign them a mentor to guide their adjustment.

\section{Potential Limitations}

Although this meta-analysis breaks new ground in the socialization literature, it is not without its potential limitations. First, meta-analysis is a summary tool that depends on previous studies. Although there are many studies of socialization, sample sizes and the number of studies on which some of the current meta-analytic correlations were based were relatively small in some cases. As a result, some of the estimated meta-analytic correlations may be unstable. Thus, it was not possible to study these correlations more closely than the summary path model (i.e., we could not perform effect size moderator analyses). In general, studies including selfefficacy were more scarce than other types of adjustment. Clearly, more studies are needed to be able to estimate these correlations with greater precision and to test for additional moderators for some of the relationships studied.

The socialization literature has approached the measurement of the antecedents of information seeking and tactics in different ways. One important difference is composite versus facet measures of these constructs. A challenge in the current study was to maximize our ability to include as many studies of socialization as possible in our path analysis to help us summarize the literature succinctly. To do this, we created composite variables for information seeking and tactics. Doing this allowed us to include all studies that included these variables. The downside, however, is that this overall model obscures the different potential relationships among the facets of information seeking, tactics, adjustment, and socialization outcomes. Therefore, we conducted follow-up analyses of the specific facet relationships with adjustment as well as the outcomes. Thus, we were able to meet our goal of summarizing the literature with an overall path model while also analyzing the interrelationships of the specific facets.

\section{Future Research Directions}

On the basis of conducting this meta-analysis, we have some specific recommendations for future research. First, we recommend that researchers always present a correlation matrix; we found several studies that we could not include because they did not. Second, we recommend that socialization researchers clearly report the time of measurement for all of the variables. We found that the type and timing of data collection mattered. Therefore, this information is key to include in the method section of socialization studies. Third, researchers including facet-based measures should 
report results for specific facets as well as composites. This practice will help facilitate future meta-analyses on this topic.

In addition, one of the major goals of this study was to understand what areas of socialization are in need of additional studies. We found several areas in which this is true, including learning, innovation, and the role of time in socialization. Despite the importance of learning as part of the socialization process, researchers have not consistently examined the role of learning. Researchers should build on the work of studies that tap learning, such as Ostroff and Kozlowski (1993) and R. F. Morrison and Brantner (1992), as it seems that there is still a need for more research examining learning as a proximal outcome of socialization.

Most of the socialization studies continued to focus on distal outcomes of the socialization, including job satisfaction, organizational commitment, and turnover intentions (Bauer et al., 1998). When socialization is viewed as an uncertainty reduction process, more proximal outcomes should include actual learning of tasks as well as organizational norms and values. In this article, we have focused on the most often studied outcomes of the socialization process, including job satisfaction, organizational commitment, performance, and turnover. These distal outcomes have been associated with newcomer socialization through a process of uncertainty reduction. However, these outcomes may not necessarily be desirable to all organizations. In fact, a small number of researchers noticed a tradeoff between role innovation and organizational commitment. For example, Jones (1986) as well as Allen and Meyer (1990) showed that institutionalized tactics were positively related to commitment, but they were negatively related to role innovation. Some organizations may even be interested in a certain level of person-organization misfit to achieve desirable outcomes such as innovative behaviors. It seems that more research is necessary that examines role innovativeness as an outcome. We identified some studies that examined this outcome but not in sufficient numbers to include this outcome in our path model. Still, this is an important outcome to study. Depending on the organization's culture, organizations may be interested in increasing ambiguity, or using individualized tactics, despite their potentially negative relationship with organizational commitment. Given the importance of innovation as an outcome for some organizations, more research is needed.

The length of the time it takes newcomers to adjust has been of consistent concern to socialization researchers. For example, Fisher (1986) noted that "socialization is a dynamic process in which individuals and organizations change over time. Many studies have failed to handle the time dimension appropriately" ( $\mathrm{p}$. 103). Bauer et al. (1998) noted that organizational socialization researchers made large strides from 1986 to 1998 in terms of conducting longitudinal studies of socialization and noted that researchers have tended to gather information at 3-month intervals including entry, 3 months, 6 months, 9 months, and 1 year following entry. We found similar time intervals for the studies included in this meta-analysis, with entry, 3 months, and 6 months being the most frequently used intervals for data collection, but we found a great deal of variance in timing as well. Further related to the issue of time and socialization, Ostroff and Kozlowski (1992) showed that there were differences in individual patterns of information acquisition over time. However, we were unable to examine trajectories of individuals because of the global nature of the data. We recommend that future researchers use alternative data analytic approaches such as hierarchical linear modeling to examine the role of time since entry. Such research will allow us to make more specific recommendations regarding what matters most at different points in the adjustment process.

Similarly, areas of research that seem to hold promise but were not studied in sufficient numbers to include in the path model include new outcomes such as destructive employee behaviors and creative employee behaviors. These key behaviors should be influenced by culture and the socialization process. Additional areas of future research that may prove useful include the role of organizational and national culture on newcomer adjustment. For example, initial work by Kim, Cable, and Kim (2005) on socialization in South Korea as well as work with samples of individuals in Hong Kong (e.g., Fu, Shaffer, \& Harrison, 2005; E. W. Morrison, Chen, \& Salgado, 2004; Taormina \& Bauer, 2000) indicate that socialization matters a great deal in Asian cultures. Although theorists have noted some similarities and differences during international socialization (e.g., Chao, 1997; Feldman, 1997), this challenging work is worthy of further pursuit given the global nature of work today. Finally, the role of technology will continue to influence the socialization process. For example, Wesson and Gogus (2005) found that computer-conducted orientations were as effective as face-to-face orientations for information-based content areas, but they were less effective for socially rich content areas. Furthermore, Wells (2006) found relationships among tactics, learning, and trust in virtual teams. Future research should continue to examine the changing role that technology plays in the socialization process.

In conclusion, our findings show that role clarity, self-efficacy, and social acceptance mediate the relationship between newcomer information seeking and organizational socialization tactics and socialization outcomes, including newcomer performance, work attitudes, and turnover. The methodological choices socialization researchers make, such as using composite or facet measures of tactics and information seeking, have implications for the estimated relationships between these variables and adjustment and the outcomes. Moreover, whether school-to-work or work-to-work transitions are studied and whether variables are measured at the same time or with a time lag have implications for the relationships. Our study indicates that newcomer socialization continues to be an interesting and promising avenue of research.

\section{References}

References marked with an asterisk indicate studies that contributed at least one correlation to the meta-analysis. Some studies included more than one unique sample. Any studies that shared the same sample were coded only once, but both have an asterisk. Therefore, the number of studies with asterisks does not exactly match the number of independent samples included in the meta-analysis. A complete list of all studies considered is available by request from Talya N. Bauer.

*Adkins, C. L. (1995). Previous work experience and organizational socialization: A longitudinal examination. Academy of Management Journal, 38, 839-862.

*Allen, D. (2006). Do organizational socialization tactics influence newcomer embeddedness and turnover? Journal of Management, 32, 237256.

*Allen, N. J., \& Meyer, J. P. (1990). Organizational socialization tactics: A longitudinal analysis of links to newcomers' commitment and role orientation. Academy of Management Journal, 33, 847-858. 
*Ashford, S. J., \& Black, J. S. (1996). Proactivity during organizational entry: A role of desire for control. Journal of Applied Psychology, 81, 199-214.

Ashforth, B. E. (2001). Role transitions in organizational life: An identitybased perspective. Mahwah, NJ: Erlbaum.

*Ashforth, B. E., \& Saks, A. M. (1995). Work-role transitions: A longitudinal examination of the Nicholson model. Journal of Occupational and Organizational Psychology, 68, 157-175.

*Ashforth, B. E., \& Saks, A. M. (1996). Socialization tactics: Longitudinal effects on newcomer adjustment. Academy of Management Journal, 39, $149-178$.

*Ashforth, B. E., Saks, A. M., \& Lee, R. T. (1998). Socialization and newcomer adjustment: The role of organizational context. Human Relations, 51, 897-926.

Ashforth, B. E., Sluss, D. M., \& Harrison, S. H. (in press). Socialization in organizational contexts. International Review of Industrial and Organizational Psychology.

*Barksdale, H. C., Bellenger, D. N., Boles, J. S., \& Brashear, T. G. (2003). The impact of realistic job previews and perceptions of training on sales force performance and continuance commitment: A longitudinal study. Journal of Personal Selling \& Sales Management, 23, 125-138.

Bauer, T. N., \& Elder, E. (2006, June). Onboarding newcomers into organizations. Presentation at the Society for Human Resource Management Annual Meeting, Washington, DC.

Bauer, T. N., \& Green, S. G. (1994). The effect of newcomer involvement in work-related activities: A longitudinal study of socialization. Journal of Applied Psychology, 79, 211-223.

*Bauer, T. N., \& Green, S. G. (1998). Testing the combined effects of newcomer information seeking and manager behavior on socialization. Journal of Applied Psychology, 83, 72-83.

Bauer, T. N., Morrison, E. W., \& Callister, R. R. (1998). Organizational socialization: A review and directions for future research. In G. R. Ferris (Ed.), Research in personnel and human resource management (Vol. 16, pp. 149-214). Greenwich, CT: JAI Press.

Bauer, T. N., \& Taylor, M. S. (2001). A globalized conceptualization of organizational socialization. In N. Anderson, D. S. Ones, H. K. Sinangil, \& C. Viswesvaran (Eds.), International handbook of industrial, work, and organizational psychology (Vol. 1, pp. 409-423). New York: Sage.

Berger, C. R. (1979). Beyond initial interaction: Uncertainty, understanding, and the development of interpersonal relationships. In H. Giles \& R. N. St. Clair (Eds.), Language and social psychology (pp. 122-144). Baltimore: University Park Press.

Berger, C. R., \& Calabrese, R. J. (1975). Some explorations in initial interaction and beyond: Toward a developmental theory of interpersonal communication. Human Communication Research, 1, 99-112.

Bhuasskar-Shrinivas, P., Harrison, D. A., Shaffer, M. A., \& Luk, D. M. (2005). Input-based and time-based models of international adjustment: Meta-analytic evidence and theoretical extensions. Academy of Management Journal, 48, 257-281.

Bravo, M. J., Peiro, J. M., Rodriguez, I., \& Whitely, W. T. (2003). Social antecedents of the role stress and career-enhancing strategies of newcomers to organizations: A longitudinal study. Work and Stress, 17, 195-217.

*Buckley, M. R., Fedor, D. B., Veres, J. G., Wiese, D. S., \& Carraher, S. M. (1998). Investigating newcomer expectations and job-related outcomes. Journal of Applied Psychology, 83, 452-461.

Bureau of Labor Statistics. (2005). Retrieved December 8, 2005, from http://www.bls.gov/nls/nlsfaqs.htm\#anch

*Cable, D. M., \& Parsons, C. K. (2001). Socialization tactics and personorganization fit. Personnel Psychology, 54, 1-23.

*Cardon, M. S. (2001, April). The impact of anticipated tenure on satisfaction, commitment, and performance of newcomers. Paper presented at the annual meeting for the Society for Industrial and Organizational Psychology, Chicago, IL.
*Carr, J. C., Pearson, A. W., Vest, M. J., \& Boyar, S. L. (2003, August). Expectations, perceived congruence, and occupational experience effects on voluntary turnover. Paper presented at the annual meeting of the Academy of Management, Seattle, WA.

Carr, J. Z., Schmidt, A. M., Ford, J. K., \& DeShon, R. P. (2003). Climate perceptions matter: A meta-analytic path analysis relating molar climate, cognitive and affective states, and individual level work outcomes. Journal of Applied Psychology, 88, 605-619.

Chao, G. T. (1997). Complexities in international organizational socialization. International Journal of Assessment and Selection, 5, 9-13.

Chao, G. T., O’Leary-Kelly, A. M., Wolf, S., Klein, H. J., \& Gardner, P. D. (1994). Organizational socialization: Its content and consequences. Journal of Applied Psychology, 79, 730-743.

*Chatman, J. A. (1991). Matching people and organizations: Selection and socialization in public accounting firms. Administrative Science Quarterly, 36, 459-484.

*Chen, G. (2005). Newcomer adaptation in teams: Multilevel antecedents and outcomes. Academy of Management Journal, 48, 101-116.

*Chen, G., \& Klimoski, R. J. (2003). The impact of expectations on newcomer performance in teams as mediated by work characteristics, social exchanges, and empowerment. Academy of Management Journal, 46, 591-607.

Cheung, M., \& Chan, W. (2005). Meta-analytic structural equation modeling: A two-stage approach. Psychological Methods, 10, 40-64.

Cohen, J. (1988). Statistical power analysis for the behavioral sciences (2nd ed.). Hillsdale, NJ: Erlbaum.

*Colarelli, S. M., Dean, R. A., \& Konstans, C. (1987). Comparative effects of personal and situational influences on job outcomes of new professionals. Journal of Applied Psychology, 72, 558-566.

*Cooper-Thomas, H. D., \& Anderson, N. (2005). Organizational socialization: A field study into socialization success and rate. International Journal of Selection and Assessment, 13, 116-128.

*Cooper-Thomas, H. D., van Vianen, A., \& Anderson, N. (2004). Changes in person-organization fit: The impact of socialization tactics on perceived and actual P-O fit. European Journal of Work and Organizational Psychology, 13, 52-78.

*De Vos, A., \& Buyens, D. (2004, August). The relationship between information seeking and changes in newcomers' psychological contracts. Paper presented at the annual meeting of the Academy of Management, New Orleans, LA.

Falcione, R. L., \& Wilson, C. E. (1988). Socialization processes in organizations. In G. M. Goldhaber \& G. A. Barnett (Eds.), Handbook of organizational communication (pp. 151-169). Norwood, NJ: Ablex.

Feldman, D. C. (1976). A contingency theory of socialization. Administrative Science Quarterly, 21, 433-452.

Feldman, D. C. (1981). The multiple socialization of organization members. Academy of Management Review, 6, 309-318.

Feldman, D. C. (1997). Socialization in an international context. International Journal of Selection and Assessment, 5, 1-8.

*Ferris, G. R., Youngblood, S. A., \& Yates, V. L. (1985). Personality, training performance, and withdrawal: A test of the person-group fit hypothesis for organizational newcomers. Journal of Vocational Behavior, 27, 377-388.

*Finkelstein, L. M., Kulas, J. T., \& Dages, K. D. (2003). Age differences in proactive newcomer socialization strategies in two populations. Journal of Business and Psychology, 17, 473-502.

*Fisher, C. D. (1985). Social support and adjustment to work: A longitudinal study. Journal of Management, 11, 39-53.

Fisher, C. D. (1986). Organizational socialization: An integrative review. In K. M. Rowland \& G. R. Ferris (Eds.), Research in personnel and human resources management (Vol. 4, pp. 101-145). Greenwich, CT: JAI Press.

Fu, C. K., Shaffer, M. A., \& Harrison, D. A. (2005, August). Proactive socialization, adjustment and turnover: A study of self-initiated foreign 
employees. Paper presented at the Academy of Management Annual Meeting, Honolulu, HI.

*Grimes, C. (2002). Socialization of newcomers: An investigation of tactic use and related outcomes. Unpublished master's thesis, California State University, Long Beach.

*Hart, Z. P., \& Miller, V. D. (2005). Context and message content during organizational socialization: A research note. Human Communication Research, 31, 295-309.

*Haueter, J. A., Macan, T. H., \& Winter, J. (2003). Measurement of newcomer socialization: Construct validation of a multidimensional scale. Journal of Vocational Behavior, 63, 20-39.

Hedges, L., \& Olkin, I. (1985). Statistical methods for meta-analysis. New York: Academic Press.

*Holton E. F., III, \& Russell, C. G. (1997). The relationship of anticipation to newcomer socialization processes and outcomes: A pilot study. Journal of Occupational and Organizational Psychology, 70, 163-172.

Hunter, J. E., \& Schmidt, F. L. (1990). Methods of meta-analysis: Correcting error and bias in research findings. Newbury Park, CA: Sage.

*Jones, G. R. (1986). Socialization tactics, self-efficacy, and newcomers' adjustments to organizations. Academy of Management Journal, 29, 262-279.

*Kammeyer-Mueller, J. D., \& Wanberg, C. R. (2003). Unwrapping the organizational entry process: Disentangling multiple antecedents and their pathways to adjustment. Journal of Applied Psychology, 88, 779794

*Kammeyer-Mueller, J. D., Wanberg, C. R., Glomb, T. M., \& Ahlburg, D. (2005). Turnover processes in a temporal context: It's about time. Journal of Applied Psychology, 90, 644-658.

Kim, T., Cable, D. M., \& Kim, S. (2005). Socialization tactics, employee proactivity, and person-organization fit. Journal of Applied Psychology, 90, 232-241.

*Kirchmeyer, C. (1995). Demographic similarity to the work group: A longitudinal study of managers at the early career stage. Journal of Organizational Behavior, 16, 67-83.

*Klein, H. J., Fan, J., \& Preacher, K. J. (2004, April). The effects of early socialization experiences on the mastery of socialization content and socialization outcomes: A mediational approach. Paper presented at the annual meeting for the Society for Industrial and Organizational Psychology, Chicago, IL.

*Klynn, B. J. (2001). Getting new executives on-board: Investigating an integrated theory of organizational socialization. Dissertation Abstracts International, 61 (12), 6747B. (UMI No. AAT 9999407)

*Laker, D. R., \& Steffy, B. D. (1995). The impact of alternative socialization tactics on self-managing behavior and organizational commitment. Journal of Social Behavior and Personality, 10, 645-660.

*Liden, R. C., Bauer, T. N., Erdogan, B., \& Wayne, S. J. (2004, April). New employee socialization: Factors influencing the process. Paper presented at the annual meeting of the Society for Industrial and Organizational Psychology, Chicago, IL.

Lipsey, M., \& Wilson, D. (2001). Practical meta-analysis. Thousand Oaks, CA: Sage.

Louis, M. R. (1980). Surprise and sense making: What newcomers experience in entering unfamiliar organizational settings. Administrative Science Quarterly, 25, 226-251.

Louis, M. R., Posner, B. Z., \& Powell, G. N. (1983). The availability and helpfulness of socialization practices. Personnel Psychology, 36, 857866

*Mabey, C., Clark, T., \& Daniels, K. (1996). A six year longitudinal study of graduate expectations: The implications for company recruitment and selection strategies. International Journal of Selection and Assessment, 4, 139-150.

*Maertz, C. P., Boyar, S., \& Pearson, A. (2005). Theory-based development of a comprehensive survey of turnover and attachment motives. Unpublished manuscript.
*Maertz, C. P., Griffeth, R., Campbell, N., \& Allen, D. (2005). The effects of perceived organizational and supervisor support on turnover: A study of mediated and interactive effects. Unpublished manuscript.

*Maier, G., \& Brunstein, J. C. (2001). The role of personal work goals in newcomers' job satisfaction and organizational commitment: A longitudinal analysis. Journal of Applied Psychology, 86, 1034-1042.

*Major, D. A., Kozlowski, S. W. J., Chao, G. T., \& Gardner, P. D. (1995). A longitudinal investigation of newcomer expectations, early socialization outcomes, and the moderating effects of role development factors. Journal of Applied Psychology, 80, 418-431.

*Meyer, J. P., \& Allen, N. J. (1988). Links between work experiences and organizational commitment during the first year of employment: A longitudinal analysis. Journal of Occupational Psychology, 61, 195209.

*Mignerey, J. T., Rubin, R. B., \& Gorden, W. I. (1995). Organizational entry: An investigation of newcomer communication behavior and uncertainty. Communication Research, 22, 54-85.

Miller, V. D., \& Jablin, F. M. (1991). Information seeking during organizational entry: Influences, tactics, and a model of the process. Academy of Management Review, 16, 92-120.

*Morrison, E. W. (1993a). Longitudinal study of the effects of information seeking on newcomer socialization. Journal of Applied Psychology, 78, 173-183.

*Morrison, E. W. (1993b). Newcomer information seeking: Exploring types, modes, sources, and outcomes. Academy of Management Journal, $36,557-589$.

*Morrison, E. W. (2002). Newcomers' relationships: The role of social network ties during socialization. Academy of Management Journal, 45, $1149-1160$.

Morrison, E. W., Chen, Y., \& Salgado, S. R. (2004). Cultural differences in newcomer feedback seeking: A comparison of the United States and Hong Kong. Applied Psychology: An International Review, 53, 1-22.

Morrison, R. F., \& Brantner, T. M. (1992). What enhances or inhibits learning a new job? A basic career issue. Journal of Applied Psychology, 77, 926-940.

*Nelson, D. L., Quick, J. C., \& Eakin, M. E. (1988). A longitudinal study of newcomer role adjustment in U.S. organizations. Work and Stress, 2, $219-253$.

Nunnally, J. C., \& Bernstein, I. H. (1994). Psychometric theory (3rd ed.). New York: McGraw-Hill.

*O'Reilly, C. A., III, \& Caldwell, D. F. (1981). The commitment and job tenure of new employees: Some evidence of postdecisional justification. Administrative Science Quarterly, 26, 597-616.

*Ostroff, C., \& Kozlowski, S. W. J. (1992). Organizational socialization as a learning process: The role of information acquisition. Personnel Psychology, 45, 849-874.

Ostroff, C., \& Kozlowski, S. W. (1993). The role of mentoring in the information gathering processes of newcomers during early organizational socialization. Journal of Vocational Behavior, 42, 170-183.

Reichers, A. E. (1987). An interactionist perspective on newcomer socialization rates. Academy of Management Review, 12, 278-287.

*Reio, T. G., \& Callhan, J. L. (2004). Affect, curiosity, and socializationrelated learning: A path analysis of antecedents to job performance. Journal of Business and Psychology, 19, 3-22.

*Riordan, C. M., Weatherly, E. W., Vandenberg, R. J., \& Self, R. M. (2001). The effects of pre-entry experiences and socialization tactics on newcomer attitudes and turnover. Journal of Managerial Issues, 13, $159-176$.

*Robinson, S. L., \& Morrison, E. W. (2000). The development of psychological contract breach and violation: A longitudinal study. Journal of Organizational Behavior, 21, 525-546.

Rollag, K., Parise, S., \& Cross, R. (2005). Getting new hires up to speed quickly. MIT Sloan Management Review, 46, 35-41. 
Rosenthal, R. (1991). Meta-analytic procedures for social research (rev. ed.). Newbury Park, CA: Sage.

Rosenthal, R., \& Rubin, D. B. (1986). Meta-analytic procedures for combining studies with multiple effect sizes. Psychological Bulletin, 99, 400-406.

*Saks, A. M. (1995). Longitudinal field investigation of the moderating and mediating effects of self-efficacy on the relationship between training and newcomer adjustment. Journal of Applied Psychology, 80, 211-225.

*Saks, A. M., \& Ashforth, B. E. (1996). Proactive socialization and behavioral self-management. Journal of Vocational Behavior, 48, 301323

Saks, A. M., \& Ashforth, B. E. (1997a). Organizational socialization: Making sense of past and present as a prologue for the future. Journal of Vocational Behavior, 51, 234-279.

*Saks, A. M., \& Ashforth, B. E. (1997b). Socialization tactics and newcomer information acquisition. International Journal of Selection and Assessment, 5, 48-61.

*Saks, A. M., \& Ashforth, B. E. (2000). The role of dispositions, entry stressors, and behavioral plasticity theory in predicting newcomers' adjustment to work. Journal of Organizational Behavior, 21, 43-62.

*Saks, A. M., Taggar, S., \& Ashforth, B. E. (2004, April). A self-regulatory conceptualization of newcomer proactive socialization. Paper presented at the annual meeting of the Society for Industrial and Organizational Psychology, Chicago, IL.

*Saks, A. M., \& Waldman, D. A. (1998). The relationship between age and job performance evaluations for entry-level professionals. Journal of Organizational Behavior, 19, 408-419.

*Settoon, R. P., \& Adkins, C. L. (1997). Newcomer socialization: The role of supervisors, coworkers, friends and family members. Journal of Business and Psychology, 11, 507-516.

*Sias, P. M., Kramer, M. K., \& Jenkins, E. (1997). A comparison of the communication behaviors of temporary employees and new hires. Communication Research, 24, 731-754.

Taormina, R. J. (1994). The Organizational Socialization Inventory. International Journal of Selection and Assessment, 2, 133-145.

Taormina, R. J. (2004). Convergent validation of two measures of organizational socialization. International Journal of Human Resource Management, 15, 76-93.

Taormina, R. J., \& Bauer, T. N. (2000). Organizational socialization in two cultures: Results from the United States and Hong Kong. International Journal of Organizational Analysis, 8, 263-290.

*Teboul, J. C. B. (1995). Determinants of new hire information-seeking during organizational encounter. Western Journal of Communication, $59,305-326$.
*Tekleab, A. G. (2003). The role of realistic job previews and organizational socialization on newcomers' psychological contract development. Dissertation Abstracts International, 64 (11), 4125A. (UMI No. AAT 3112503)

*Vandenberg, R. J., \& Scarpello, V. (1990). The matching model: An examination of the processes underlying realistic job preview. Journal of Applied Psychology, 75, 60-67.

Van Maanen, J., \& Schein, E. H. (1979). Toward a theory of organizational socialization. Research in Organizational Behavior, 1, 209-264.

*Van Vianen, A. E. M. (2000). Person-organization fit: The match between newcomers' and recruiters' preferences for organizational cultures. Personnel Psychology, 53, 113-149.

*Wanberg, C. R., \& Kammeyer-Mueller, J. D. (2000). Predictors and outcomes of proactivity in the socialization process. Journal of Applied Psychology, 85, 373-385.

Wanous, J. (1980). Organizational entry: Recruitment, selection, and socialization of newcomers. Reading, MA: Addison-Wesley.

Wanous, J., \& Colella, A. (1989). Organizational entry research: Current status and future directions. In G. R. Ferris \& K. M. Rowland (Eds.), Research in personnel and human resources management (Vol. 7, pp. 59-120). Greenwich, CT: JAI Press.

*Waung, M. (1995). The effects of self-regulatory coping orientation on newcomer adjustment and job survival. Personnel Psychology, 48, 633650 .

Wells, K. (2006, May). Enabling tactic knowledge-sharing in virtual teams: The role of socialization. In T. Bauer (Chair), Organizational socialization research: Summary, redefinition, and new research directions. Symposium at the annual meeting of the Society for Industrial and Organizational Psychology, Dallas, TX.

*Wesson, M. J. (2002). The employee who knew too much? An examination of the interaction between prior work experience, information seeking, and the socialization of organizational newcomers. Dissertation Abstracts International, 63(09), 3261A. (UMI No. AAT 3064330)

*Wesson, M. J., \& Gogus, C. I. (2005). Shaking hands with a computer: An examination of two methods of newcomer orientation. Journal of Applied Psychology, 90, 1018-1026.

*Zahrly, J., \& Tosi, H. (1989). The differential effect of organizational induction process on early work role adjustment. Journal of Organizational Behavior, 10, 59-74.

Received August 3, 2005

Revision received June 25, 2006

Accepted July 25, 2006 